MATEC Web of Conferences 25, 04002 (2015)

DOI: $10.1051 /$ matecconf/ 20152504002

(C) Owned by the authors, published by EDP Sciences, 2015

\title{
Comparative Research of Extra-large-span Cable-stayed Bridge with Steel Truss Girder and Steel Box Girder
}

\author{
Manjiang Tan, Zhizhou Bai \& Dewei Chen \\ Tongji University, Shanghai, China
}

\begin{abstract}
To research structural performance of extra-large-span cable-stayed bridge under different section forms, with the engineering background of a $800 \mathrm{~m}$ main-span cable-stayed bridge with steel truss girder, the cable-stayed bridge with steel box girder is designed according to the current bridge regulations when two bridges are designed in an ultimate state of the carrying capacity, so the maximum stress and minimum stress of the stress envelope diagram are substantially the same. A comprehensive comparison is given to two types of bridge on the aspect of static force, natural vibration frequency, stability, economic performance and so on. Analysis results provide future reference for the large-span cable-stayed bridge to select between the steel truss girder and the steel box girder.
\end{abstract}

Keywords: $\quad$ steel truss girder; steel box girder; large-span cable-stayed bridge; comparative analysis

\section{INTRODUCTION}

Cable-stayed bridge is one of China's most popular bridge types among large-span bridges. Among the large-span cable-stayed bridges that have been built up, the steel box girder is widely used. The following reasons are analyzed by the author: simple structural design, convenient construction, welding and bolting, safe and reliable structure; the steel box girder commonly adopts factory prefabrication and spot lifting construction, which can effectively shorten the construction period with attractive appearance. However, the steel box girder also has some disadvantages, for example, transportation and lifting of the prefabricated steel box girder need certain transportation and site conditions; it is difficult for relatively small lateral stiffness and vertical stiffness to ensure smooth running of high-speed trains and passenger comfort and so on. In recent years, with the construction of Yachi River Bridge, Hutong Yangtze River Bridge, Tianxingzhou Yangtze River Bridge and other large-span cable-stayed bridge with steel truss girder, the large-span cable-stayed bridges are gradually applied to rail transport and some places with poor transport conditions.

\section{PROJECT OVERVIEW}

The engineering project in this paper is an extra-large-span cable-stayed bridge of Yachi River under construction in China.

It is an extra-large-span cable-stayed bridge with steel truss girder with the bi-directional four-lane road on the bridge floor and the design speed of $80 \mathrm{Km} / \mathrm{h}$; the bridge site is located in Guizhou Province, crossing Yachi River and connected with Guiyang and south Guizhou, which is an important part of highway engineering from Guiyang in Guizhou Province to south Guizhou.

The extra-large bridge of Yachi River adopts a semi-floating system with span layout of $72+72+76+800+76+72+72=1240 \mathrm{~m}$, wherein: the side span is a prestressed concrete box girder, the mid-span is a structure of steel truss girder, and the ratio between the side span and the mid-span is 0.275 , as shown in Figure 1. The main structure of steel truss girder adopts "N" type truss, it is horizontally arranged with two main trusses. The center spacing is $27.0 \mathrm{~m}$, the height of standard truss segment is $7.0 \mathrm{~m}$, and the segment length is $8.0 \mathrm{~m}$. At present, the extra-large bridge of Yachi River is at the construction phase of main tower. It will become a world record holder among the world's similar type of bridges (cable-stayed bridge with steel truss girder) when completed.

3 FINITE ELEMENT MODELING OF CABLE-STAYED BRIDGE WITH STEEL TRUSS GIRDER

Modeling adopts finite element software Midas; the girder, pier and cable bent tower adopt beam element for simulation; the stay cable adopts cable element for simulation. Main materials select following parameters:

The side-span box girder uses C55 concrete, the modulus of elasticity is $3.55 \times 10^{4} \mathrm{Mpa}$, the Poisson's ratio is 0.2 and the volume weight is $26 \mathrm{kN} / \mathrm{m}^{3}$; the pier and bridge tower uses $\mathrm{C} 50$ concrete, the modulus of elasticity is $3.45 \times 10^{4} \mathrm{Mpa}$, the Poisson's ratio is 0.2 and the volume weight is $26 \mathrm{kN} / \mathrm{m}^{3}$. Q420D is used for upper and lower chord of the stiffening truss girder 
MATEC Web of Conferences

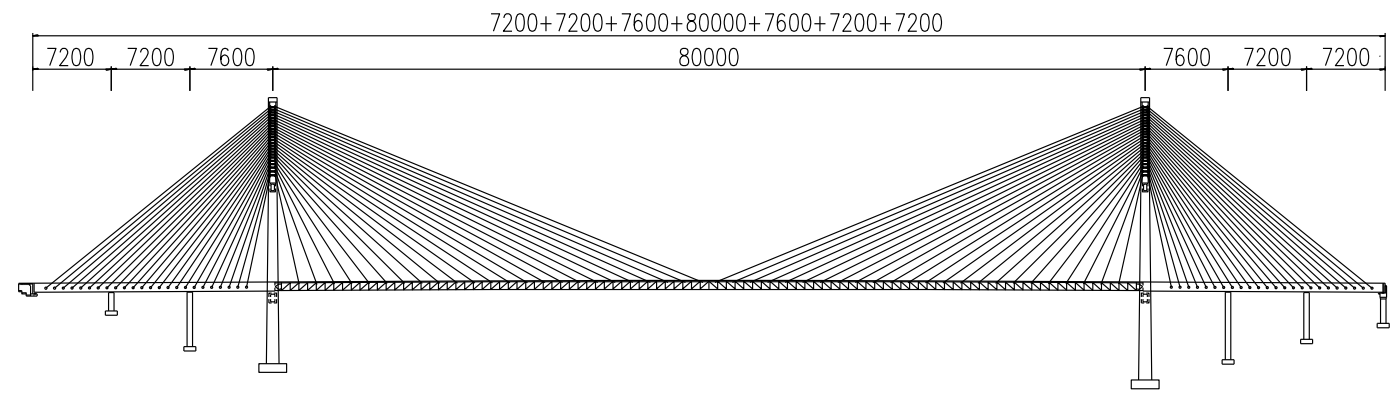

Figure 1. General layout (unit: $\mathrm{cm}$ )

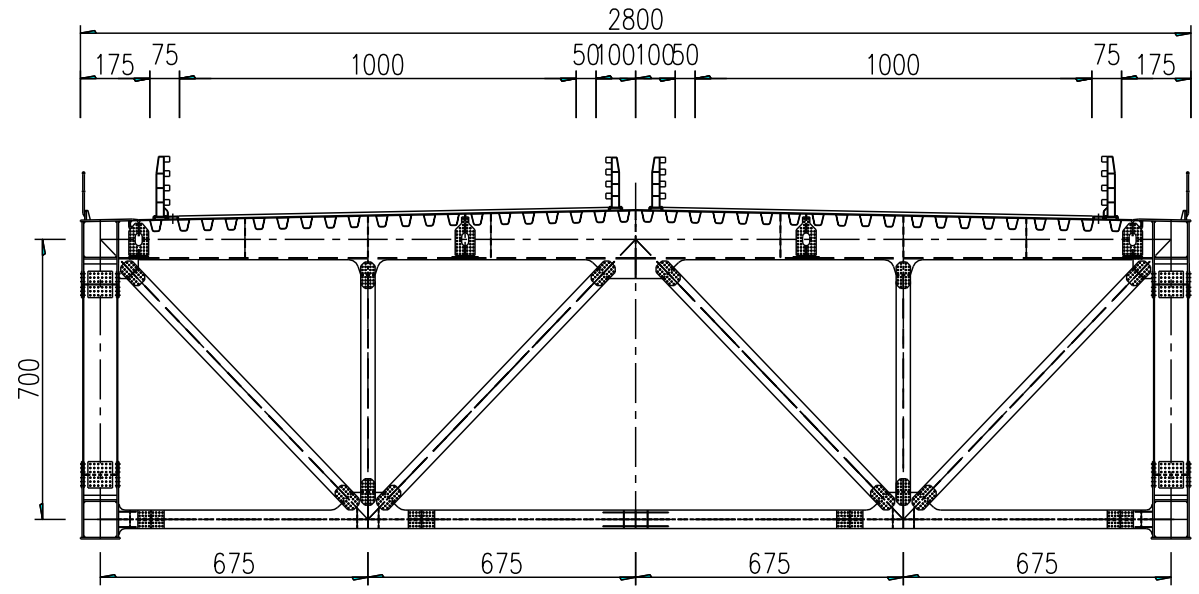

Figure 2. Cross-sectional view of the steel truss girder (unit: $\mathrm{cm}$ )

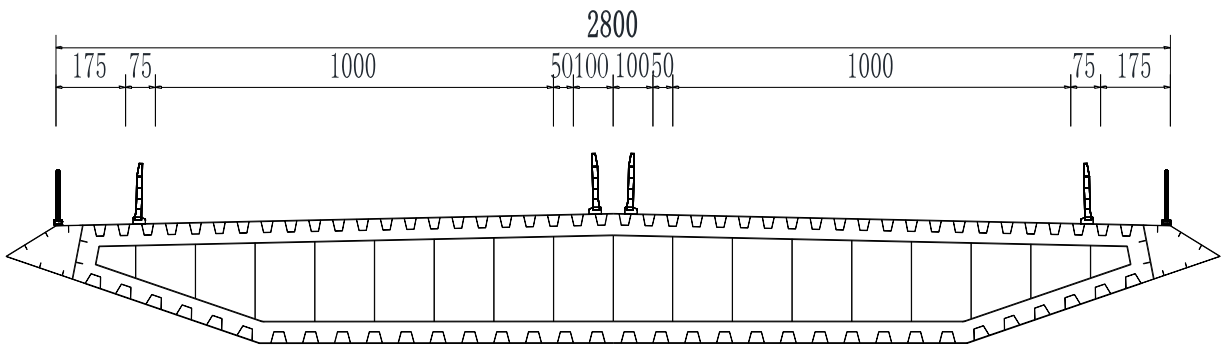

Figure 3. Cross-sectional view of the steel box girder (unit: $\mathrm{cm}$ )

with the plate thickness of $40 \mathrm{~mm}$, the modulus of elasticity is $2.06 \times 10^{5} \mathrm{Mpa}$, and the Poisson's ratio is 0.3 . Q345D is used for upper and lower chord of the stiffening truss girder and the web member, upper and lower chord of the cross girder and the web member, bottom lateral bracing, orthotropic steel bridge deck, with the plate thickness which is less than $40 \mathrm{~mm}$, the modulus of elasticity is $2.06 \times 10^{5} \mathrm{Mpa}$, the Poisson's ratio is 0.3 . The volume weight of upper chord of main truss takes the value of $131 \mathrm{kN} / \mathrm{m}^{3}$, while the volume weight of lower chord of main truss takes the value of $127.4 \mathrm{kN} / \mathrm{m}^{3}$. The cross section of the steel truss girder is shown in Figure 2.

Constraint condition: the pounding bottom and the bridge bottom are fully consolidated, while bridge tower and abutment restrain horizontal and longitudinal displacement of main girder bridge without restraining the longitudinal displacement of the main girder. 


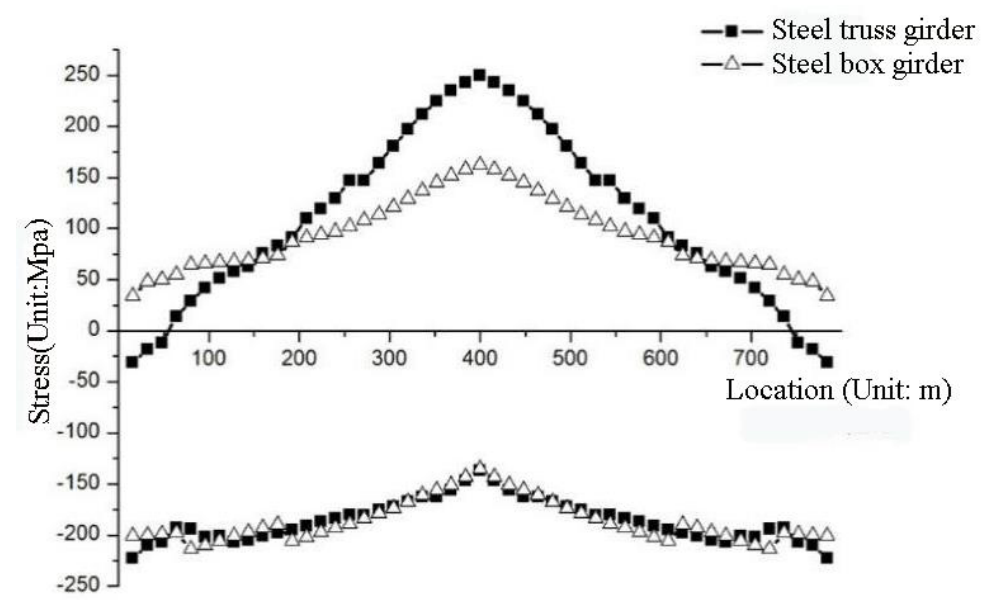

Figure 4. Envelope diagram of the girder stress in an ultimate state of the carrying capacity

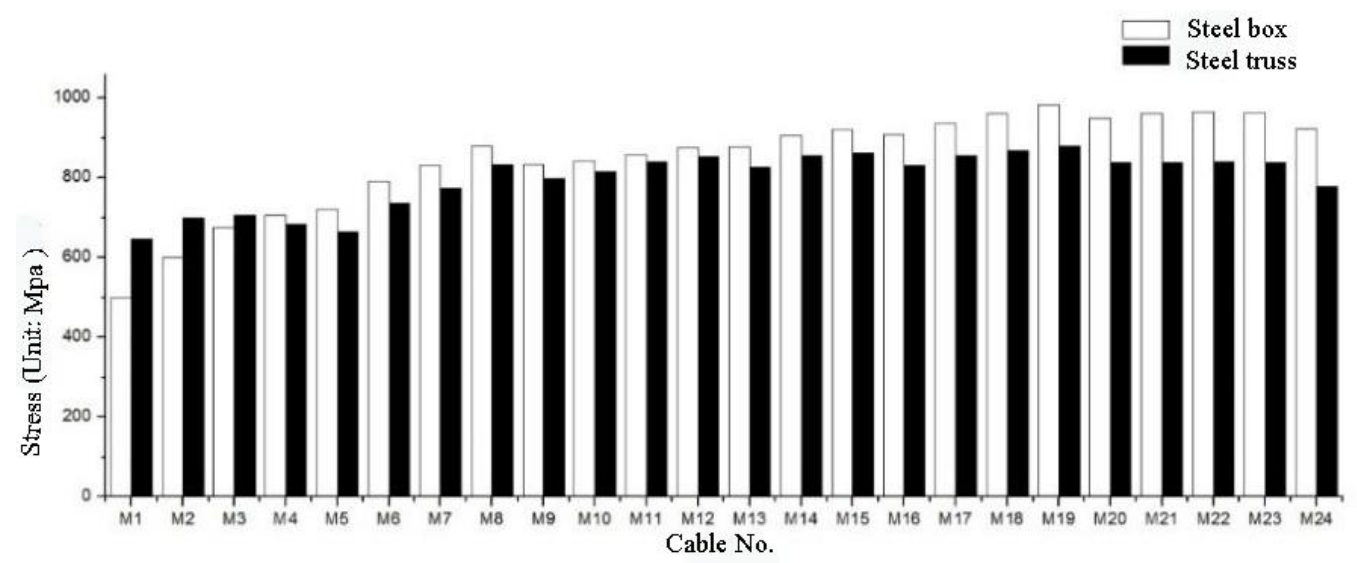

Figure 5. Maximum stress of stay cable in an ultimate state of the carrying capacity

4 FINITE ELEMENT MODELING OF CABLE-STAYED BRIDGE WITH STEEL BOX GIRDER

The side span and bridge tower of the cable-stayed bridge with steel truss girder keep the same with that of the cable-stayed bridge with the steel box girder, only changing the section form of the main span, and displacing the steel truss girder with the steel box girder. The section form of the steel box girder initially adopts the approach to combine with former engineering projects and refer to the current specification.

The stress envelope diagram of the steel box girder in an ultimate state of the carrying capacity can be calculated by adopting the initially proposed section to substitute the full-bridge model and the trial calculation by the finite element of MIDAS based on the stress envelope diagram through the height adjustment of the box girder section, the bottom of the steel box girder, the thickness of the top plate and cable-stayed force. So the maximum stress and the minimum stress of the steel box girder in each longitudinal segment to the bridge are substantially the same with the upper and lower chord of the steel truss girder in the corresponding segments, and the stress of stay cable is substantially the same with the maximum stress of each cable in the stress envelope diagram in an ultimate state of the carrying capacity. Meanwhile, the steel box bridge at the construction stage and finished stage meets the standard requirement. After repeated trial calculation, the ultimate section of the box girder is shown in Figure 3, and the height of the box girder is $3 \mathrm{~m}$.

The top plate adopts two different thicknesses--- $16 \mathrm{~mm}$ and $18 \mathrm{~mm}$ in different segments towards the bridge, of which the plate with the largest thickness is near the cable bent tower. For the U-shaped stiffening rib of the top plate, the width of its upper opening is $300 \mathrm{~mm}$, the width of its lower opening is $180 \mathrm{~mm}$, and the spacing is $6,000 \mathrm{~mm}$. For the 


\section{MATEC Web of Conferences}

U-shaped stiffening rib, its thickness is $8 \mathrm{~mm}$, and the height is $290 \mathrm{~mm}$. The base plate adopts two different thicknesses---16mm and $18 \mathrm{~mm}$ in different segments towards the bridge, of which the plate with the largest thickness is near the cable bent tower. For the U-shaped stiffening rib of the bottom plate, the width of its upper opening is $250 \mathrm{~mm}$, the width of its lower opening is $400 \mathrm{~mm}$, and the spacing is $8,000 \mathrm{~mm}$. For the U-shaped stiffening rib, its thickness is $8 \mathrm{~mm}$, and the height is $260 \mathrm{~mm}$.

The steel box girder adopts Q345D, with the modulus of elasticity of $2.06 \times 10^{5} \mathrm{Mpa}$, Poisson's ratio of 0.3 , and volume weight of $87.94 \mathrm{kN} / \mathrm{m}^{3}$.

A comparison between the stresses of the steel box girder and the steel truss girder in an ultimate state of the carrying capacity is shown in Figure 4 and Figure 5. The figures show that, in an ultimate state of the carrying capacity, though the maximum tension stress has a slight deviation, the maximum pressure stresses of two bridges are substantially the same, and the envelope area of coordinate axis is also substantially the same. Except for individual cables with relatively large derivation, other cable force is substantially the same for the maximum stress of stay cable with the maximum deviation which is less than $15 \%$.

\section{COMPARISON OF DEFLECTION OF AUTO LIVE LOAD}

Calculated by Road Grade I load, considering multilane reduction coefficient and vertical reduction coefficient, six lanes are loaded based on the influence line to achieve a girder deflection diagram, which is shown in the following figure:

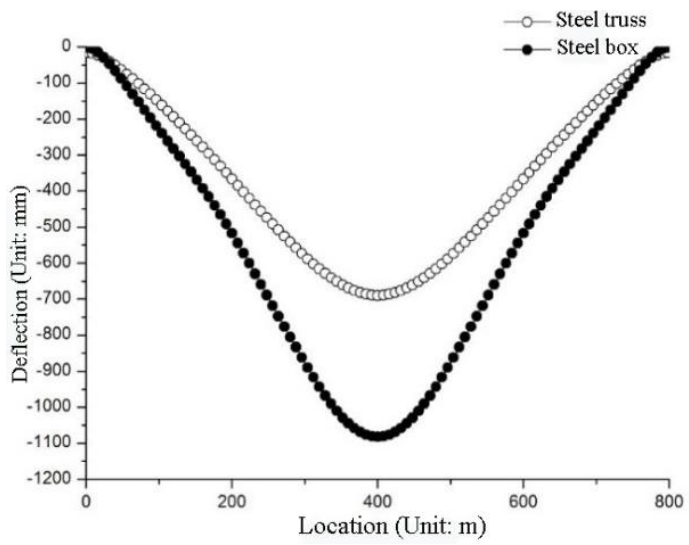

Figure 6. Girder deflection diagram of auto load

From the above figure, when six lanes are loaded on the lane loading, the maximum vertical displacement of the mid-span of the steel box girder is $1082 \mathrm{~mm}$, and the maximum vertical displacement of the mid-span of the steel truss girder is $-690 \mathrm{~mm}$. The mid-span deflection of the steel truss girder is $36 \%$ smaller than that of the steel box girder.

\section{COMPARISON OF NATURAL VIBRATION FREQUENCY}

The natural vibration frequency of two bridges is analyzed by adopting multiple Ritz vector method. Multiple Ritz method refers to a subspace iteration method, which adopts multiple initialization vectors when generating Ritz space. To simply obtain condemnation matrix, the basic equation adopts an equivalent transformation form of an original issue, which is specifically as follows:

Assume that $\boldsymbol{K}$ is positive definite, then:

\section{$K X=\lambda M X$}

It can be an equivalent problem:

\section{$M K^{-1} M Y=\xi M Y$}

It is easy to demonstrate the relationship between two characteristics:

$$
\left\{\begin{array}{c}
\mathbf{X}_{\mathrm{i}}=\mathbf{Y}_{\mathrm{i}} \\
\lambda_{\mathrm{i}}=1 / \xi_{\mathrm{i}}
\end{array}\right.
$$

From (3), calculate the low frequency of previous orders in (1) is equivalent to calculate the high frequency of previous orders in (2). According to the basic idea of the power method, we can carry out a series of direct iteration on (2) to generate Ritz vector space, and then calculate the best approximate solution in Ritz space of high order characteristics of the previous orders in (2), and finally calculate the best approximate solution of low order characteristics of the previous orders in (1) by the transformation of (3).

This paper adopts the Midas finite element program and the multiple Ritz vector method to conduct modal analysis for two bridges, the natural vibration frequency and the corresponding vibration mode of two bridges based on each modal of the previous ten orders are shown in Table 1.

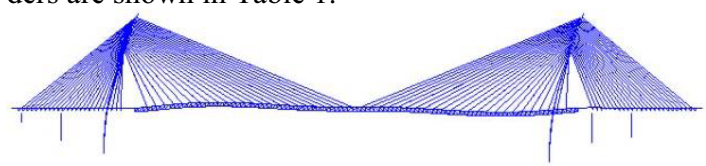

Figure 7. Longitudinal floatation of the natural vibration frequency at the first order

Comparative analysis of the natural vibration characteristics of two bridges has following features:

(1)The fundamental frequency of the cable-stayed bridge with steel truss girder is $0.394 \mathrm{~Hz}$, and the fundamental frequency of the cable-stayed bridge with steel box girder is $0.405 \mathrm{~Hz}$. The cable-stayed bridge with steel truss girder has a little difference in the fundamental frequency and presents longitudinal floatation, which reflects small longitudinal stiffness of the cable-stayed bridge in a semi-floating system. 
EMME 2015

Table 1. Comparison of natural vibration characteristics of two bridges

\begin{tabular}{|c|c|c|c|}
\hline Modal No. & Bridge type & Frequency $(\mathrm{Hz})$ & Characteristics of vibration mode \\
\hline \multirow{2}{*}{1} & Steel truss girder & 0.394 & Longitudinal floatation \\
\hline & Steel box girder & 0.405 & Longitudinal floatation \\
\hline \multirow[t]{2}{*}{2} & Steel truss girder & 1.042 & $\begin{array}{l}\text { Symmetric lateral bending of the girder } \\
\text { Symmetric lateral bending of the girder }\end{array}$ \\
\hline & Steel box girder & 0.527 & Symmetric lateral bending of the girder \\
\hline \multirow{2}{*}{3} & Steel truss girder & 1.427 & Different lateral bending of main tower \\
\hline & Steel box girder & 1.370 & Lateral bending of right tower \\
\hline \multirow{2}{*}{4} & Steel truss girder & 1.464 & Symmetric vertical bending of the girder \\
\hline & Steel box girder & 1.435 & Symmetric vertical bending of the girder \\
\hline \multirow{2}{*}{5} & Steel truss girder & 1.590 & Same lateral bending of main tower \\
\hline & Steel box girder & 1.546 & Lateral bending of left tower \\
\hline \multirow{2}{*}{6} & Steel truss girder & 1.996 & Anti-symmetric vertical bending of the girder \\
\hline & Steel box girder & 1.825 & Anti-symmetric vertical bending of the girder \\
\hline \multirow{2}{*}{7} & Steel truss girder & 2.536 & Different lateral bending of right tower column \\
\hline & Steel box girder & 1.969 & Girder reverse \\
\hline \multirow{2}{*}{8} & Steel truss girder & 2.536 & Different lateral bending of left tower column \\
\hline & Steel box girder & 2.427 & Symmetric vertical bending of the girder \\
\hline \multirow{2}{*}{9} & Steel truss girder & 2.686 & Girder reverse \\
\hline & Steel box girder & 2.554 & Different lateral bending of right main tower \\
\hline \multirow{2}{*}{10} & Steel truss girder & 2.699 & Symmetric vertical bending of the girder \\
\hline & Steel box girder & 2.554 & Different lateral bending of left main tower \\
\hline
\end{tabular}

Table 2. Comparison of stability calculation of two bridges at the finished bridge stage

\begin{tabular}{llll}
\hline Modal No. & Bridge type & Frequency $(\mathrm{Hz})$ & Characteristics of vibration mode \\
\hline \multirow{2}{*}{1} & Steel truss girder & 5.455 & Longitudinal floatation \\
& Steel box girder & 5.018 & Longitudinal floatation \\
2 & Steel truss girder & 7.736 & Local buckling of steel truss on the left tower \\
\multirow{3}{*}{3} & Steel box girder & 6.306 & Vertical bending of girder \\
& Steel truss girder & 8.132 & Local buckling of steel truss on the right tower \\
4 & Steel box girder & 6.362 & Vertical bending of girder \\
& Steel truss girder & 8.907 & Local buckling of steel truss on the left tower \\
5 & Steel box girder & 6.452 & Symmetric vertical bending of girder \\
& Steel truss girder & 8.992 & Local buckling of steel truss on the right tower \\
\hline
\end{tabular}

(2) The fundamental frequency of lateral bending of the cable-stayed bridge with steel truss girder is $1.042 \mathrm{~Hz}$, and the fundamental frequency of the cable-stayed bridge with steel box girder is $0.527 \mathrm{~Hz}$ The fundamental frequency of lateral bending of the cable-stayed bridge with steel truss girder is much greater than that of the steel box girder, which reflects that the lateral stiffness of the cable-stayed bridge with steel truss girder is larger than that of the steel box girder.

(3) The fundamental frequency of vertical bending of the cable-stayed bridge with steel truss girder is $1.464 \mathrm{~Hz}$, and the fundamental frequency of the cable-stayed bridge with steel box girder is $1.435 \mathrm{~Hz}$. The fundamental frequency of vertical bending of two bridges has a little difference.

(4) The fundamental frequency of the cable-stayed bridge's reverse with steel truss girder is $2.686 \mathrm{~Hz}$, and the fundamental frequency of the cable-stayed bridge with steel box girder is $1.969 \mathrm{~Hz}$. The fundamental frequency of the cable-stayed bridge's reverse with steel truss girder is much greater than that of the steel box girder, which reflects that the reverse stiffness of the cable-stayed bridge with steel truss girder is larger than that of the steel box girder.

\section{COMPARISON OF BUCKLING MODE}

The stability of steel structures is prevalent in the design of steel structures. Usually, there is a need to carefully consider the stability of the pressed parts of the structure in the design.

Based on the structure, buckling phenomenon of a large-span cable-stayed bridge can be divided into: overall buckling, stability of cable bent tower or stability of girder, and local stability of cable bent tower or girder component, for example, the local warping of the bridge deck or web of steel box girder under pressure, the local buckling of the sectional web of steel tower and so on.

This paper solves the first class of elastic stability of the steel box girder and steel truss girder by the use of Midas finite element software. 


\section{MATEC Web of Conferences}

The finished bridge state of the structure can be an analysis target to examine stable condition of the structure; in the process of calculation, we assume that the structure has completed the whole concrete shrinkage and creep process (10 years), while those mainly analyzed variable loads are dead loads of the structure, paving load at the second phase and tension of stay cable.

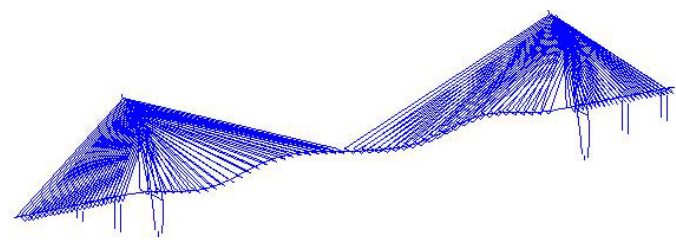

Figure 8. Buckling mode of longitudinal floatation

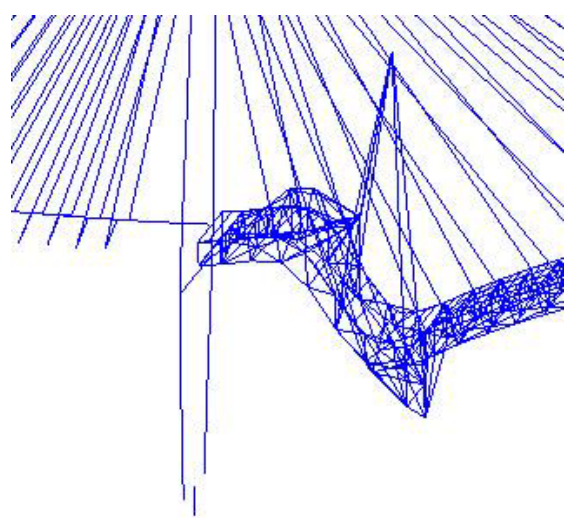

Figure 9. Local buckling mode of steel truss girder on the second order

Analysis shows that the buckling of the steel box girder on the previous five orders is buckling in plane, which is mainly an overall buckling of girder. For the steel truss girder except for longitudinal floatation on the first order, from the second order to the fifth order is local buckling of steel truss girder of the cable bent tower.

\section{COMPARION OF ENGINEERING COVERAGE}

Major engineering coverage is shown in the following table:

Table 3. Major engineering coverage

\begin{tabular}{lll}
\hline & Steel box girder & Steel truss girder \\
\hline $\begin{array}{l}\text { Rolled steel for } \\
\text { main span (T) }\end{array}$ & 10501 & 18945 \\
$\begin{array}{l}\text { Steel strand for } \\
\text { stay cable (T) }\end{array}$ & 2601 & 3602 \\
\hline
\end{tabular}

From the data in this table, the quantity of steel used for the main-span steel box is less about $45 \%$ than that of the steel truss girder, and the used roller steel is about $28 \%$ less than that of the steel truss girder. Therefore, based on the same stress indicators, if only the economic performance of the material is considered, the economic performance of the steel box girder is much better than that of the steel truss girder.

\section{CONCLUSION}

(1) After the comparison of natural vibration frequency and the comparison of deflection of auto live load, based on the vertical stiffness of the cable-stayed bridge with steel box girder designed by the same stress indicator, its lateral stiffness and torsional stiffness are smaller than that of the cable-stayed bridge with steel truss girder. There is a need to pay more attention to the problem of deflection in the design of steel box girder.

(2) Buckling analysis shows that the steel box girder is prone to overall bucking, while the steel truss girder is prone to local buckling. In the design, there is a need to pay more attention to overall buckling of the steel box girder and local buckling of the steel truss girder of the cable bent tower due to too large pressure stress.

(3) For the cable-stayed bridge with steel box girder designed by the same stress indicator, if only considering materials used in engineering, its economic performance is significantly better than that of the cable-stayed bridge with steel truss girder. In the practical engineering, we should comprehensively consider whether transportation and construction are used for road or railway, and select an appropriate section form.

\section{REFERENCES}

[1] Guohao Li. 1996. Stability and vibration of bridge structure. Beijing: China Railway Press.

[2] Shilin Liu, ZhitaoLiang, Jinlong Hou. \& Fanchao Meng. 2002. Cable-stayed bridge. Beijing: China Communications Press.

[3] Standards of Ministry of Transportation of the People's Republic of China. General design specifications of highway bridges and culverts (JTGD60-2004) [S]. Beijing: China Communications Press, 2004

[4] Recommended industry standards of the People's Republic of China. Design details of highway cable-stayed bridge (JTG / T D65-01-2007) [S]. Beijing: China Communications Press, 2007

[5] Haiquan Li. \& Cunguo Wang. 2011. Analysis of buckling and stability of the cable-stayed bridge with broad superposed girder. Railway Construction, (5): 22-24

[6] Wangxing Ding. \& Yousheng Jiang. 2011. Design of Jingyue Bridge . Bridge Construction, (4): 57-61

[7] Bingjing Lu. 2009. Finite element analysis of cable-stayed bridge with steel box girder. Master's Thesis of Chang'an University. 